\title{
13. Tuvacada çokluk anlamı veren sözcükler ile bu sözcüklerin kullanım özellikleri
}

\section{Fatoş KARADAĞ TOPRAK}

APA: Karadağ Toprak, F. (2021). Tuvacada çokluk anlamı veren sözcükler ile bu sözcüklerin kullanım özellikleri. RumeliDE Dil ve Edebiyat Araştırmaları Dergisi, (23), 187-198. DOI: 10.29000/rumelide.948320.

\section{$\ddot{O} \mathbf{z}$}

Çokluk yapıları dünya dillerinde olduğu gibi Türk dilinde de önemli bir yere sahiptir. Dilde nesneleri ya da kavramları sınıflama yollarından bir tanesi de çokluk kategorisidir. Türk dilinde çokluk; anlam bakımından çokluk içeren sözler, çokluk ekleri ve yalın halde ya da bazı hal ekleri kullanarak isimleri tekrarlama yani çokluk bildiren zarflarla, sayı sözcükleriyle yapılabilir. Çoğunlukla sayı kategorisi altında değerlendirilen çokluk, aslında sayılabilirlik kadar belirsizliği de bünyesinde barındırmaktadır. Bu yönüyle sıfatlarla, zamirlerle ya da zarflarla belirsiz çokluk yapmak mümkündür. Bu çalışmada da çokluk bildiren sıfat, zamir ya da zarflar yoluyla çokluk anlamının sağlanmasına değinilmiştir. Leksik olarak çokluk anlamını taşıyan sözcüklerin sentaktik olarak kullanım özellikleri üzerinde durulmuştur. Güney Sibirya Bölgesi'nde konuşulan Türk dillerinden birisi olan Tuvacadaki çokluk yapıları çalışmanın odak noktasını oluşturmaktadır. Tuvaca gramerlerde zamir olarak değerlendirilen sözcüklerin cümlede çokluk anlamını sağlamak için zarf, sıfat ya da yine zamir olarak kullanımına dair örnekler sunulmuştur. Bu bağlamda çokluk anlamı taşıyan sözlerin sentaktik işlevlerine açıklanmış ayrıca bu işlevler Tuvaca metinlerden seçilen cümleler ile örneklendirilmiştir. Bu sözcüklerle ilgili olarak sınırlı bir biçimde etimolojik bilgiler de verilmiştir. Böylelikle Türk dilinin arkaik unsurlarını iyi koruyan kollarından birisi olan Tuvacanın bir kısım sözlerle sentaktik olarak belirsiz çokluk yapısını nasıl sağladığı ortaya konmaya çalışılmıştır.

Anahtar kelimeler: Tuvaca, çokluk yapıları, sentaktik çokluk

\section{The plural lexemes in Tuvan and usage features of these words}

\begin{abstract}
Plural forms have an important place in Turkish language as well as in world languages. One of the ways to classify objects or concepts in language is the pluralitiy category. Plurality in Turkish language; Words that contain a plurality in terms of meaning can be made with plural suffixes and repeating names in simple or using some case suffixes, that is, with adverbs and number words. The plurality, which is mostly evaluated under the category of numbers, actually includes uncertainty as well as countability. In this respect, it is possible to make indefinite plurality with adjectives, pronouns or adverbs. In this study, providing the meaning of the plural by means of adjectives, pronouns or adverbs indicating multiplicity is mentioned. The syntactic usage properties of the words that have the meaning of lexical plurality are emphasized. Plurality structures in Tuvan, one of the Turkish languages spoken in the Southern Siberian Region, constitute the focus of the study. Examples of the use of words considered as pronouns in Tuvanian grammars as adverbs, adjectives
\end{abstract}

Arş. Gör. Çukurova Üniversitesi, Fen Edebiyat Fakültesi, Türk Dili ve Edebiyatı Bölümü (Adana, Türkiye), karadagfatos@hotmail.com, ORCID ID: 0000-0002-5019-3432 [Araştırma makalesi, Makale kayıt tarihi: 02.02.2021kabul tarihi: 20.06.2021; DOI: 10.29000/rumelide.948320]

Adres $\mid$ Address

RumeliDE Dil ve Edebiyat Araşttrmaları Dergisi $\quad$ RumeliDE Journal of Language and Literature Studies Osmanağa Mahallesi, Mürver Çiçeği Sokak, No:14/8 $\quad$ Osmanağa Mahallesi, Mürver Çiçeği Sokak, No:14/8

Kadıköy - İSTANBUL / TÜRKIYE 34714 Kadıköy - ISTANBUL / TURKEY 34714 e-posta: editor@rumelide.com

e-mail: editor@rumelide.com,

tel: +90 505 7958124, +90 2167730616 phone: +90 505 7958124, +90 2167730616 
or also pronouns in order to provide the meaning of plurality in sentences are presented. In this context, the syntactic functions of the words that have the meaning of the multitude are explained and these functions are exemplified with the sentences selected from the Tuvan texts. Limited etymological information is also given about these words. Thus, it has been tried to reveal how Tuvan, which is one of the branches of the Turkish language that protects the archaic elements well, provides syntactically ambiguous plurality form.

Keywords: Tuvans, plural forms, syntactic plurality

\section{Giriş}

Çokluk kavramı nesnelerin, varlıkların sayılabilirlik açısından birden fazla olduğunu gösteren yapıları bünyesinde barındırır. Dünya dillerinin bir kısmında nesnelerin sayı veya adet açısından durumları; teklik, tesniye (ikilik) ve çokluk olarak üç grupta değerlendirilmektedir. Bazı dillerde tesniye kategorisi bulunmadığı için kavram ve nesneler iki temel grupta değerlendirilmektedir. Türk dilinde de tesniye (ikilik) kategorisi bulunmamaktadır (ìlhan, 2009, s.13). Bu sebeple teklik ve çokluk kategorileri ile nesnelerin sayılabilirlik durumları iki ulamda incelenmektedir.

Çokluk kavramı dilbilgisel olarak isim ve zamirlerde birden çok varlı̆̆ı, çekimli eylemlerde birden çok kişiyi çeşitli eklerle gösteren biçim olarak tanımlanır (Topaloğlu, 2019, s.45). Ayrıca çokluk tekliğin karşıtı olan bir dilbilgisel ulam olarak da tanımlanır (Vardar, 2002, s.62). Çokluk kavramı sınırları oldukça geniş bir kavramdır. Türkçede çoğunlukla sayı başlı̆̆ altında değerlendirilen çokluk bildiren sözcükler diller için başlangıçta gerçek çokluğu bildirmiş olsa da sonraları anlatımı güçlendirme ve özellikle abartma işlevinde de kullanılmışlardır (Çetin, 2018, s.66). Çokluk çatısının altına bütünlük bildiren sözler, topluluk bildiren sözler de dâhil edilebilir. Topluluk bildiren sözcükler kendi içlerinde çokluk anlamını taşımaktadırlar. Toplu çokluk, kendi sözlüksel anlamını kendi içerisinde barındırmaktadır (Ödemiş, 2017, s.1448). Bütünlük bildiren sözler de aynı şekilde bütünlük- çokluk ilişkisi sebebiyle çokluk çatısı altında değerlendirilebilir.

Çokluk gramerlerde çoğul ve çokluk terimleriyle karşılanmış² ve yapılan çalışmalar çokluk eki olan $+L A r$ etrafında morfolojik çalışmalar olarak şekillenmiştir. Çalışmalar çokluk ekine odaklansa da Türkçede çokluk çeşitli şekillerde yapılmaktadır. Bunlar; semantik olarak çokluk ifade eden sözcükler, +LAr çokluk eki çokluk bildiren zarflar ve sayı sözcükleridir (İsina, 1997, s.114).

Türk dilinde bilindiği üzere niceliği belli olan çokluk için sayı sözcükleri kullanılır. Bir ismin önüne gelerek onun niceliğini gösteren sözcükler sıfat işlevinde kullanılan sayı sözcükleridir. Bir de belirsiz çokluğu gösteren; belirsizlik sıfatları, belirsizlik zamirleri, azlık-çokluk bildiren sözcükler bulunmaktadır. Bunlar sınırları çizilemeyen çokluğu işaretlemektedirler (Torun, 2014, s.296). Çalışmanın odak noktasını da bu sözcükler oluşturmaktadır. Sayılamayan çokluğu ya da bütünlüğü gösteren bu sözcükler Tuva gramerlerinde genellikle zamir kategorisinde değerlendirilmişlerdir. Ancak bizim gramercilik anlayışımızla incelendiğinde bu sözcüklerin sıfat, zamir ya da zarf görevinde kullanıldığını, sentaktik açıdan bakıldığında işlevinin farklılaştığı görülmektedir. Aslında bu sözcükler aynı zamanda semantik olarak da çokluk anlamını taşıan sözcüklerdir.

C. Emre, V. Hatiboğlu, T.N. Gencan, , B. Vardar çoğul; M. Mansuroğlu, M. Ergin, K. Eraslan, Zeynep Korkmaz çokluk; T. Banguoğlu ise çoklu terimini kullanan araştırmacılardandır.

Adres $\mid$ Address

RumeliDE Dil ve Edebiyat Araşttrmalar Dergisi $\quad$ RumeliDE Journal of Language and Literature Studies Osmanağa Mahallesi, Mürver Çiçeği Sokak, No:14/8 Osmanağa Mahallesi, Mürver Çiçeği Sokak, No:14/8

Kadıköy - İSTANBUL / TÜRKIYE 34714 Kadıköy - ISTANBUL / TURKEY 34714 e-posta: editor@rumelide.com

e-mail: editor@rumelide.com,

tel: +90 505 7958124, +90 2167730616 phone: +90 505 7958124, +90 2167730616 
Çalışma kapsamında oluşturulan metin örnekleminde belirsiz çokluk anlamını taşıyan zamir, zarf ve sıfat işlevinde kullanılan yapılar tespit edilmiştir. Ayrıca metin örnekleminde rastlayamadığımız ancak sözlük ve gramerlerde yer alan yapılar için başka çalışmalardan örnekler eklenmiştir. Her bir sözcük için Tuvacanın dört farklı sözlüğüne başvurulmuştur. Bunlardan birisi Tuvacanın Tatarintsev tarafından hazırlanan Etimologiçeskiy Slovar Tuvinskogo Yazıka adlı dört ciltlik etimolojik sözlüğüdür. Ancak son yayımlanan S maddesine ulaşılamadığından bu maddeye kadar olan dört cildinden faydalanılmıştır. İki ciltten oluşan Tıva Dıldı Tayılbırlıg Slovarı (Tuva Dilinin Açıklamalı Sözlüğü) bir başka başvuru kaynağımızdır. Ancak bu sözlüğün de tüm maddeleri tam değildir. Tenişev redaktörlüğünde hazırlanan 22.00o sözcükten oluşan Tuvisko-Russkiy Slovar tüm maddelerin tam olduğu başvuru kaynaklarımızdandır. Ayrıca M. Ölmez’in Tuvacanın Eski Türkçe ile Tuvacanın söz varlığını karşılaştırmalı olarak sunduğu Tuvacanın Söz Varhı̆̆, Eski Türkçe ve Moğolca Denkleriyle adlı çalışma da çalışma kapsamında başvurulan kaynaklardandır.

\section{Tuvacada çokluk anlamı veren sözcükler ile bu sözcüklerin kullanım özellikleri}

arbın (арбын): “çok, sayısız” [ESTY I: 129; TuvRus:66; TS:148 TW:77].

Arbın sözcüğü Tuvacada çokluk anlamını sağlamak için kullanılan sözcüklerden biridir. Aynı şekilde Kırgızcada arbın "pek, çok", Altaycada arbın " çok, fazla", Hakasçada arban arbın "iri, çok, büyük" sözcükleri çokluk anlamında Sibirya Bölgesi ve etrafında kullanılmaktadır. Sözcüğün kökenine bakıldığında Moğolca arbin arvin" "çok, bol, bereketli” sözcüğü ile ilişkili olduğu görülür (Tatarintsev, 2000, s.129-130). Böylelikle sözcüğün Moğolca bir ödünçleme olduğunu söylemek mümkündür. Kullanım işlevleri açısından incelendiğinde sözcüğün azlık- çokluk sıfatı ya da zarfı görevinde kullanıldığı örnekler tespit edilmiştir.

\section{Stfat olarak kullanm?}

хөй хураган, арбын дүк беер чартык нарын дүктүг уксааның хоюн өстүреринге баштайгы дуржулга ажылынга дидим болгаш идепкейлии-биле киришкени

... höy huragan, arbın dük beer çartık narın düktüg uksaanıñ hoyun östüreringe baştaygı durjulga ajılınga didim bolgaş idepkeylii-bile kirişkeni (Koçoğlu Gündoğdu, 2018, s.389).

“... çok kuzu ve çok yün veren karışık koyun cinsini yetiştirmenin ilk denemelerine aktif olarak ve cesaretle katılmalartdr."

\section{Zarfolarak kullanme}

Хөй туман тыртып, чаап арткан тайгазындан баткаш, ол башкы Кызыл-Дагга кеерге, ында езирик кижи арбын болган.

Höy tuman tırtıp, çaap artkan taygazından batkaş, ol başkı Kızıl-Dagga keerge, ında yezirik kiji arbın bolgan.(Koçoğlu Gündoğdu, 2018, s. 456).

"Dumanl, yağmurlu taygasından inen lama Kızıl-Dağ’a geldiğinde burada sarhoşların çok olduğunu görmüştür.”(Koçoğlu Gündoğdu, 2018, s.578).

büdün (бүдүн) :"bütün, tek bir maddeden, tamam” [ESTY I: 310; TuvRus:125; TS I: 325; TW: 103].

Tuvacada bütünlük yapısı ile çokluk anlamı veren sözlerden olan büdün, Eski Türkçede de bütün şekliyle aynı anlamda bulunmaktadır. Clauson fiilin büt- "bitmek, tükenmek" fiiline eklenen /- ü/ ya da /i-/ sesi ve onun da üzerine gelen /-n/ ile türediğini belirtmektedir (1972, s. 306b). DLT'de "tam" anlamında büte sözünün var olduğu görülmektedir ( Kaçalin; Ölmez; 2019, s.135). Moğolcada da

\footnotetext{
Adres $\mid$ Address

RumeliDE Dil ve Edebiyat Araşttrmaları Dergisi $\quad$ RumeliDE Journal of Language and Literature Studies Osmanağa Mahallesi, Mürver Çiçeği Sokak, No:14/8 Osmanağa Mahallesi, Mürver Çiçeği Sokak, No:14/8 Kadıköy - ISTANBUL / TÜRKIYE 34714 Kadıköy - ISTANBUL / TURKEY 34714 e-posta: editor@rumelide.com e-mail: editor@rumelide.com, tel: +90 505 7958124, +90 2167730616 phone: +90 505 7958124, +90 2167730616
} 
bütün " tam, bütün, iyi durumda" anlamı ile varlığını sürdürmektedir (Lessing, akt: Karaağaç, 2003, s.246). Moğolcada bütü- ve büte- şeklinde iki farklı fiil bulunmaktadır. Bu da fiilin Proto- Türkçe döneminde geniş zaman ekleriyle çekimlenen fiil kökleri olduğuna işarettir (Ünal, 2016, s.193). Hem Eski Türkçede hem Moğolcada bulunan büdün sözcüğü Moğolcanın etkisiyle Tuvacanın söz varlığında yer almıştır. Bu sözün Tuvacada sıfat olarak kullanım özelliği gösterdiği tespit edilmiştir.

\section{Syfat olarak kullanm?}

Bir nesnenin statik gruplarını işaretleyen söz grubu olarak adlandırılan (İshakov\& Palmbah, 2019, s.179) sıfatlar nesneleri pek çok yönden betimler. Bunlardan birisi de sözcügün önüne belgisiz sıfat getirilerek çokluk ya da bütünlük anlamı kazandırılmasıdır.

Бүдүн өгнүң иштинден чүгле чаңныс мен артып калган (ÇU /20).

Büdün ögnüy iştinden çügle çangıs men artıp kalgan.

"Bütün ailenin içinden sadece yalnız ben kalmışım."

Шаанда бүдүн чыл дургузунда аңнап турган (АТ/203).

Şaanda büdün çll durguzunda añnap turgan.

"Eskiden bütün yıl boyunca avlıyormuş."

Ayrıca büddün sözü Tuvacada tam sayıların kesir sayı sıfatlarında ifadesi için de kullanılmaktadır (Tosun, 2011, s.310). Burada "tam, tüm” anlamını karşılamaktadır. Aşağıdaki kullanım da bu türden örneklerdendir.

беш бүдүн үштүн ийизи beş büdün üştün iyizi “ beş tam üçte iki” (Palmbah \& İshakov, 2019, s.208).

bügü (бүгү) : "her şey, hepsi” [ESTY I:309; TuvRus:125; TS I:323; TW:103].

Tuvacada bügü ve bügüde sözleri kaynaklarda sözcük türü olarak zamir olarak yer almaktadır. Bu sözcüklerin köken bakımından Moğolca ödünçlemeler olduğu görülmektedir (Tatarintsev, 2000, s.309). Moğolcada bükü sözü "tamamen bütün hep" anlamına gelmektedir (Lessing, akt: Karaağaç, 2003, s.234). Tuvacadaki biçiminden buradan ödünçlendiği düşünülmektedir. Tuva gramerlerinde zamir olarak nitelendirilen sözcü̆ün kullanım özellikleri incelendiğinde cümlede sıfat görevini de yerine getirdiği görülmektedir.

\section{Stfat olarak kullanm?}

Кызылда бүгү Тываның арат чоннарының ынак башкызы Тока чурттап турарын билир силер бе ынчаш? (ÇU/18)

Kızılda bügü Tıvanıñ arat çonnarınıñ ınak başkızı Toka çurttap turarın bilir siler be ınçaş?

“Kızılda bütün Tuvanın, halkının sevgili eğiticisi Toka’nın yaşadığını bilir misiniz ki?”

Ол-ла бүгү бодал арлы хона берген (AST /5).

Ol-la bügü bodal arlı hona bergen.

"Işste bütün düşünce kayboluverdi."

\footnotetext{
RumeliDE Dil ve Edebiyat Arașttrmaları Dergisi Osmanağa Mahallesi, Mürver Ciçeği Sokak, No:14/8 Kadıköy - İSTANBUL / TÜRKIYE 34714 e-posta: editor@rumelide.com tel: +90 505 7958124, +90 2167730616

Address

RumeliDE Journal of Language and Literature Studies Osmanağa Mahallesi, Mürver Çiçeği Sokak, No:14/8

Kadıköy - ISTANBUL / TURKEY 34714

e-mail: editor@rumelide.com,

phone: +90 $5057958124,+902167730616$
} 


\section{Zamir olarak kullanme}

Bügü ve bügüde sözcükleri belirsizlik zamiri olarak isim çekim ekleriyle çekimlenebilir ve de tamlamalarda yer alabilir (Koçoğlu Gündoğdu, 2018, s.121). Yaygın kullanım biçimi olarak nitelendirebileceğimiz zamir olarak kullanımına dair şu örneklerler sıralanabilir:

Урянхайның бүгүде даргазынга чагыртып, шиитпирлеттирер болдурган (К /8).

Uryanhayniñ bügüde dargazınga çagırtıp, şiitpirlettirer boldurgan.

"Uryanhayın tamaminda başkanlğ a yönlendirilip, karar verdirmişlerdir."

Төмүр ам бүгүдеге ат-алдарлыг кижи апарган болгай (AST /184).

Tömür am bügüdege at-aldarlıg kiji apargan bolgay.

"Tömür şimdi hepsini ünlendirmiş olacak."

bürün (бүрүн ): “tüm, tam, hepsi” [ESTY I:317; TuvRus:128; TS I:334; TW:103].

Çokluk anlamı veren sözlerden biri olan bürün sözcüğü Moğolcadan ödünçlenen bir sözcüktür. Moğolca bürin sözcüğü ile ilişkilidir (Ölmez, 2007, s.103). Moğolcada bürin "bütün, hep, her şey" anlamıyla bulunmaktadır (Lessing, akt: Karaağaç, 2003, s.241).

\section{Syfat olarak kullanmı}

Bu sözcük Tuvacada genellikle sıfat görevinde kullanılmaktadır. Sıfat kullanımına dair tespit edilen örneklerden birkaçı şöyledir:

Бүрүн эргелиг кижи база катап аъдын мунгаш: ( ÇU/32).

Bürün ergelig kiji baza katap a'dın mungaş:

"Bütün yetkili kişiler de tekrar atına binerek..."

\section{Zarfolarak kullanme}

Bürün sözcüğü zarf işlevindeyken bile edatıyla birlikte 3. şahıs iyelik ekini alarak kullanılır (İshakov; Palmbah, 2019, s. 237). Aşağıdaki kullanım bu durumu örneklemektedir:

Ынчангаш хаанныг чазакты бүрүнү-биле деткиир ужурлуг бис (K/99).

Inçangaş haannıg çazaktı bürünü-bile detkiir ujurlug bis.

"Bu yüzden kağanlı halkı bütünüyle desteklemeliyiz."

çerle (черле) “tam, bütün, tamamen” [TuvRus:529; TW:116].

Çokluk bildiren sözcüklerden çerle sözcüğünün kökenine dair kesin bir bilgi yoktur. Fakat Ölmez (2007) sözcük için çer+le biçimini tereddütlü olarak göstermektedir (s.116). Çerle sözcüğü her zaman çokluk anlamı göstermez zaman zaman da "kesinlikle" anlamında kullanılır.

\section{Zarfolarak kullanmı}

Sözcüğün kullanım özelliklerine bakıldığında zarf olarak kullanımına dair örneklere rastlanmaktadır. Bu bağlamda aşağıdaki örnek gösterilebilir:

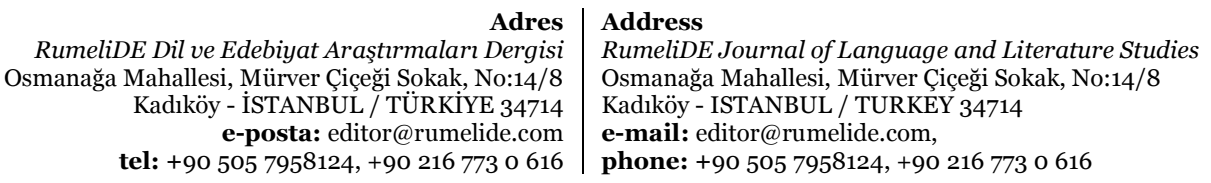


Черле елдеп кижи Мыйыс- Кулак аан деп, кадайынга Оюн Нерел чугаалаан (IB/15).

Cerle eldep kiji Mıyıs- Kulak aan dep, kadayınga Oyun Herel çugaalaan.

“Tamamıyla şaşıran adam Mıyıs- Kulak aa diyerek karısına Oyun Herel (diye) seslenmiş.”

dıka (дыка) “çok, pek, oldukça ” [ESTY II: 310; TuvRus:192; TS: 549; TW: 139].

$D \imath k a$ köken bakımından $t \hat{\imath}$ - "sürekli" sözcüğüne $-k A$ ekinin eklenmesiyle oluşmuştur (Tatarintsev, 2000, s.310-311). Sözcük Tuvacada hem derecelendirme hem de çokluk görevinde kullanılmaktadır. $D \imath k a$ sözcüğü sıfat görevinde kullanıldığında genellikle derecelendirme yapar, zarf görevinde kullanıldığında cümleye çok anlamını katmaktadır.

\section{Zarfolarak kullanm}

Дыка найыралдыг бис, ындыг болза-даа бот-бодувус аттарывыс адажыр деер кордал-даа чок $(\mathrm{AY} / 5)$.

Dıka nayıraldıg bis, ındıg bolza-daa bot-boduvus attarıvıs adajır deer kordal-daa çok.

"Çok dostça geçinen biz, öyle olsa da- kendimiz adlarımız ortak diye umutsuzuz."

Оон арнымны дыка топтуг кылыпкаш, авамга чугааладым (AY/8).

Oon arnımnı dıka toptug kılıpkaş, avamga çugaaladım.

"Ona karşı ifademi çok sakin tutarak anneme seslendim."

$D \imath k a$ sözcüğünün zarf işlevinde bir diğer kullanımı ise çokluk ifade etmesinden ziyade çokluğu pekiştirmek üzerinedir. L. Johanson (2014) Türkçede çokluğun sayllabilen varlıklarda bireyselleştirici, sayılamayan varlıklarda ise kuvvetlendirici görevde olduğunu belirtmektedir (s.97). Aşağıdaki örnekte de "çok çok" anlamını pekiştirmek amacıyla sıfat tamlamasının önünde dıka sözcüğü kullanılmıştır.

Мен лагерьге дыка хөй ештерлиг болдум, кырганавай (DÇÇ/148).

Men lager'ge dıka höy eşterlig boldum, kırganavay.

"Ben kampta pek çok arkadaş edindim, nineciğim."

dögere (дөгере): "hepsi, tamamen” [ESTY II : 226; TuvRus: 176; TS:490].

Dögere Tuvacada çokluk bildiren sözcüklerdendir. Sözcük kaynaklarda zamir olarak yer almaktadır. Köken bakımından sözcüğün döger- "bitirmek" fiilinin zarf-fiil almış şekli olduğu düşünülmektedir.

\section{Zamir olarak kullanım}

Sözcüğün zamir olarak kullanımına dair tespit ettiğimiz örneklerden ikisi şöyledir:

кандыг-даа чажыттарны дөгерезин билир ужурлуг силер (ÇU/350).

Kandıg-daa çajıttarnı dögerezin bilir ujurlug siler.

"Her türlü sakladıklarının hepsini bilmelisiniz."

Төөгү узун, дөгерезин сактып четпес, төнчүзү база билдинмес (AT/158).

Töögü uzun, dögeryezin saktıp çetpes, tönçüzü baza bildinmes.

"Tarihi uzun, hepsini hattrlamak yetmez, sonu da bilinmez."

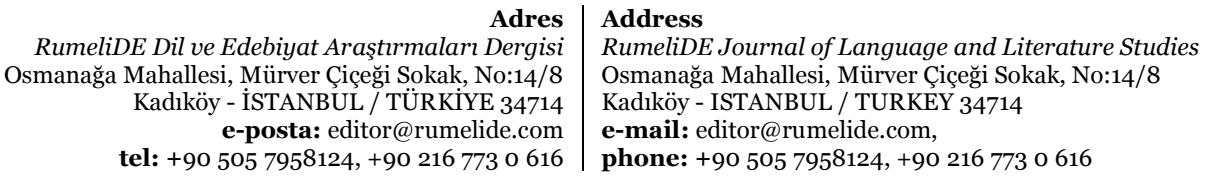


hamık (хамык) : "bütün" [TuvRus:467; TW:163].

Çokluk anlamını bünyesinde barındıran sözcüklerden biri olan hamık sözcüğü Moğolca kamug ve Eski Türkçe kamug kamag sözcükleri ile ilişkilidir. Eski Türkçe kamug kamag sözcüğünün Orta Farsça hm'g sözcüğünden geliştiği düşünülmektedir (Clauson, 1972, s.627). Moğolca hamug /kamug sözü de "bütün, tam" anlamındadır (Lessing, Çev. Karağaç,20003, s.1428). Ünal (2016) Klasik Moğolcada Türkçe kökenli çalışmaları değerlendirdiği çalışmasında kamug sözüne de yer vermiştir (s.479). Moğolcadaki biçimin Eski Türkçe biçimden ödünçlendiğini söylemek mümkündür. Tuvacadaki biçimin ise Moğolcadan mı Eski Türkçeden mi ödünçlendiğini söylemek kesin olarak mümkün değildir. Kullanım özellikleri incelendiğinde sözcüğün sıfat ve zamir görevinde kullanıldığı görülmüştür.

\section{Syfat olarak kullanm?}

Хамык күштү октаар бис (IB/40).

Hamık küştü oktaar bis.

"Bütün kuvvetimizle saldirtrzz."

Хамык улус ажылдап чоруй баргылады, чаңгыс силер-ле ажыл чок артыңар аа? (IB/74).

Hamık ulus ajıldap çoruy bargıladı, çañgıs siler-le ajıl çok artıñar aa?

"Bütün insanlar çalışıp yaşamaya yöneldi, yalnzz sizler işsiz kaldımız öyle mi?"

\section{Zamir olarak kullanım}

Оларны кадайлары- биле болгаш ажы-төлү- биле, хамык-ла оът- сиген болгаш бальзам, мөңгүн инелери, эм даштары-биле кады өргееже аъткарыпкан (ÇHDB II, s.232).

Olarnı kadayları- bile bolgaş ajı-tölü- bile, hamık-la ot- sigen bolgaş bal'zam, möñgün ineleri, em daştarı-bile kadı örgeeje a'tkarıpkan.

“Onları eşleri, çocukları, bütünüyle kuru ot olan balsam, gümüş iğneleri, ilaç taşları ile birlikte yurtlaina yolculamıs."

höy (хөй) “çok, pek çok” [TuvRus:488; TW:174].

Tuvacada kullanım sıklı̆̆ yüksek olan höy sözcüğünün kökenine dair Tuvaca kövey “ çok” sözcügünü dayandırdığımız < *köp+ey biçimi ile ilişkili olabileceği söylenebilir (Ölmez, 2007, s.174). Köp sözcüğü Eski Türkçe metinlerinde AY VIII'de köp kalın “çok, çok" ikilemesinin kullanımı bulunmaktadır (Çetin, 2017, s.731). Höy sözcüğü sıfat ve zarf işlevinde kullanılmaktadır. Sözcük sıfat olarak kullanıldığında eğer bir topluluk adını tamlıyorsa o ad çokluk eki almaz, fakat tamladığı sözcük topluluk adı değilse çokluk eki alır. Ayrıca anlatımı kuvvetlendirmek ya da pekiştirmek için eleen höy "pek çok" ve dıka höy "pek çok" sıfatları tamlayan görevinde olduğunda yine tamlanan sözcük çokluk eki alır (Tosun, 2011,s.49).

\section{Syfat olarak kullanm?}

Хөй чүве бодаар апарган мен (ÇU/549).

Höy çüve bodaar apargan men.

"Çok şey düşünmek zorunda kaldım."

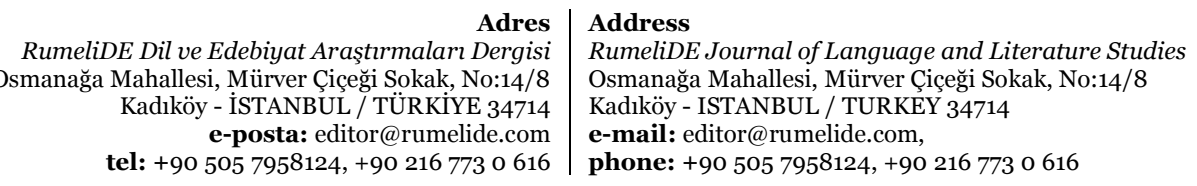




\section{Zarfolarak kullanm?}

Sözcüğün bir diğer işlevi zarf olarak kullanımıdır. Bu bağlamda tek kullanılabileceği gibi genellikle "çokça" anlamını sağlamak için höy-le ve höyü-bile şeklinde kullanılmaktadır.

Малчын кижиге ыт хөй-ле болза, эки чүве бо (АТ/ 68).

Malçın kijige it höy-le bolza, eki çüve bo.

"Çoban kişiye köpek çok olsa bu iyilik(tir)."

Aşağıdaki örnekte de sözcük belgisiz sıfatın zarfı olarak kullanılmıştır:

Хөй-хөй миллион сылдыстарлыг, кылаң дээржекайгап алгаш чытканнар (АТ/20).

Höy-höy million sıldıstarlıg, kılañ deerje kaygap algaş çıtkannar.

"Çok çok milyonlarca yıldızlı, parlak göğe doğru şaşırarak uyumuşlar."

konçug (кончуг): “çok, tamamen” [ESTY III:193; TuvRus:258; TS:169; UW:204].

Çokluk bildiren konçug Tuvacada zarf görevinde kullanılmaktadır. Sözcüğün kökeni ile ilgili olarak konçu-g- biçimi tereddütlü olarak gösterilebilir (Ölmez, 2007, s.204).

\section{Zarfolarak kullanme}

Дииң ындыг кончуг ховар эвес, элээн бар, ынчалза-даа кара ыяшта-күдүрээде (АТ/4).

Diiñ indıg konçug hovar eves, eleen bar, ınçalza-daa kara ıyaşta-küdüreede.

"Sincap öyle çok az değil epeyce var, fakat kara ormanda gevşek topraklarda."

Чүү болду? Чоп кончуг дүвүрээриң ол? (К/26).

Çü̈ boldu? Çop konçug düvüreeriñ ol?

"Ne oldu? O niçin çok telaşland??"

köñgüs ( көңгүс ): "bütün, büsbütün, oldukça” [ESTY III: 245; TuvRus: 258; TS:200; TW:207].

Çokluk bildiren sözlerden birisi olan köñüs sözcüğünün kökeni için Kırgızcada yer alan köñgü "tamamen, her şey" sözcügüne dayanarak *köñ- ortak köküne işaret edilerek *köñ-gü-s gelişimi gösterilmektedir (Tatatarintsev, 2004, s.245-246). İşlevleri açısından bakıldığında sözcüğün çokluk miktarını ifade eden bir zarf olarak kullanıldığı görülmektedir. Bu bağlamda aşağıdaki örnekler gösterilebilir:

\section{Zarfolarak kullanmm}

Көңгүс ажыы чок ыт ышкажыл (АТ/24).

Köñgüs ajı çok ıt ışkajıl.

"Bütünüyle faydasız (olan) it gibidir."

Сендиңмаа көңгүс-ле мегелепкен (АТ/84)

Sendiñmaa köñü̈s-le megelepken.

"Sediñmaa tamamen kendisini olduğundan farkh göstermiş.."

\footnotetext{
Adres | Address

RumeliDE Dil ve Edebiyat Arașttrmalar Dergisi Osmanağa Mahallesi, Mürver CCiçeği Sokak, No:14/8 Kadıköy - İSTANBUL / TÜRKIYE 34714 e-posta: editor@rumelide.com tel: +90 505 7958124, +90 2167730616

RumeliDE Journal of Language and Literature Studies Osmanağa Mahallesi, Mürver Çiçeği Sokak, No:14/8

Kadıköy - ISTANBUL / TURKEY 34714

e-mail: editor@rumelide.com,

phone: +90 505 7958124, +90 2167730616
} 
köp: (көп ) “çok, çok sayıda ” [ESTY III:212; TuvRus:258; TS:2020; TW:207].

Tuvacada çokluk bildiren sözlerden olan köp "çok" anlamıyla pek çok Türk dilinde varlığını korumuştur. Yine Eski Türkçede çokluk bildiren sözlerden olan köp sözcüğü ile ilişkilidir. Tuvacadaki köp biçimi için de aynı şeyi söylemek mümkündür. Tuvaca arkaik bir söz diyebileceğimiz köp günümüz Tuvacasında çok yaygın kullanılmamaktadır ve genellikle yerini höy sözcüğüne bırakmıştır. Sözcüğün zamir işlevine kullanımına dair aşağıdaki örnek gösterilebilir:

\section{Zamir olarak kullanme}

“кашты көрүп кажараар, көптү көрүп көгерээр.” (AN /146).

kaştı körüp kajaraar, köptü körüp kögereer.

“azı görüp kurnazlık eder, çoğu görüp yeşillenir.” (Tosun, 2011, s.121).

kövey (көвей) : “çok sayısız, fazla” [ESTY III:212; TuvRus:255; TS:186; TW:208].

Çokluk bildiren ifadelerden kövey sözcügünün köp ile ilişkili olduğu açıkça ortadadır. Tatarintsev (2004) Menges'e dayandırdığı etimolojisine göre köb-e-ye- etimolojisine yer vermektedir (s.213). Ölmez (2007) de bu görüşü destekleyerek *köp+ey- etimolojisine işaret etmektedir (s.208). Köp sözcügünün aksine kullanımı daha geniş olan çokluk ifadesidir. Sözcügün kullanım işlevlerine bakıldığında sıfat ve kezii ifadesiyle birlikte zarf olarak kullanıldığı görülmektedir.

\section{Syfat olarak kullanm?}

Aşağıdaki ifade sıfat işlevinde kullanımına bir örnektir:

Көвей чылгы аразында көк-ле борам хөрээ бедик ÇU/262).

Kövey çılgı arazında kök-le boram höree bedik

"Sayısız (çok fazla) yılkı arasında /mavi ile boz göğsümden yüksek.”

\section{Zarfolarak kullanme}

Aşağıdaki ifade ise kövey sözcüğünün zarf olarak kullanımına dair tespit ettiğimiz örneklerdendir:

Өршээп көр, өңнүк, сөзү көвей дээш мени чемелеве (АТ/126).

Örşeep kör, önnnük, sözü kövey deeş meni çemeleve.

"Bağışla, arkadaş sözü çok (fazla) diyerek beni kınama."

mırı̃̃ay (мырыңай): "bütün, büsbütün, tamamen, oldukça, hiç " [ESTY IV:219; TuvRus:306; TS:306; TW:217].

Tuvacada mirñay miray biçiminde kullanılan sözcüğün Türk dillerinde çeşitli varyantları bulunmaktadır. Bunlardan Tofaca bırıy brıy "tamamen" Hakasça pray prayzı "bütün, tamam" Tatarca pran, "tamamen" biçimlerinden hareketle sözcük ortak bir *pır köküne dayandırılsa da bu konuda bir netlik yoktur. Sözcüğün *bırıngay biçimine dayandığını söylemek mümkündür (Tatarintsev, 2008, s.222). Sözcüğün "hiç" anlamında kullanımı da mevcuttur. Fakat çokluk bildiren anlamına odaklanılacaktır.

\footnotetext{
\begin{tabular}{r|l} 
Adres & Address \\
RumeliDE Dil ve Edebiyat Araşttrmalar Dergisi & RumeliDE Journal of Language and Literature Studies
\end{tabular}

Osmanağa Mahallesi, Mürver Çiçeği Sokak, No:14/8 Osmanağa Mahallesi, Mürver Çiçeği Sokak, No:14/8

Kadıköy - İSTANBUL / TÜRKIYE 34714 Kadıköy - ISTANBUL / TURKEY 34714

e-posta: editor@rumelide.com e-mail: editor@rumelide.com,

tel: +90 505 7958124, +90 2167730616 phone: +90 505 7958124, +90 2167730616
} 


\title{
Zarfolarak kullanm?
}

Aşă̆ıdaki örnekte mırıñay sözcüğü çokluk ve bütünlük işaretleyicisi olarak eylemi nitelemektedir. $\mathrm{Bu}$ bağlamda zarf işlevinde kullanım örneğidir.

Мени мырыңай чанчапты. (АТ/12).

Meni mırıñay çançaptı.

"Beni bütünüyle parçaladr."

şuptu (шупту): “tümü, bütün, hepsi” [TuvRus: 582; TW:267].

Çokluk bildiren sözcüklerden birisi olan şuptu sözcüğü köken bakımından Moğolca ile ilişkilendirilir. Moğolcada bulunan sibtu şubtu biçimine dayanmaktadır (Ölmez, 2007, s.267). Ayrıca sözcüğün Moğolca şovtroh "sona ermek" kelimesiyle ortak bir etimolojiye sahip olduğuna dair görüşler de bulunmaktadır (Palmbah \& İshakov, 2019, s.234).

\section{Stfat olarak kullantmı}

Бистерни шупту чалчаларны, бир черге сүрүп еккелгеннер, ажылдадып кааннар. (ÇHDB II, 227).

Bisterni şuptu çalçalarnı, bir çerge sürüp ekkelgenner, ajıldadıp kaannar.

"Bizleri bütün hizmetçilerini bir yere sürerek getirmişler, çalıştırmışlardı."

\section{Zarf olarak kullanm?}

Кижилерниң салым-чолунуң нмунда шупту баш удур бижиттинген (ÇHDB II, 227).

Kijilerniñ salım-çolunuñ nomunda şuptu baş udur bijittingen.

"Kişilerin kaderinin kitabı bütünüyle önceden yazılmıştır."

tödü (төдү ): “tüm, hep, hepsi” [TuvRus:418; TW:276].

Tödü sözcüğü bütünlük yoluyla çokluk bildiren sözcüklerdendir. Sözcüğün etimolojisine dair herhangi bir bilgiye rastlanmamıştır. Kullanım özellikleri dikkate alındığında sıfat görevinde kullanımına dair özellikler tespit edilmiştir.

\section{Sifat olarak kullantmı}

\begin{abstract}
Баарында хем шаагайнып, бир-ле чүвениң дугайын төдү чугаалап чадаан ышкаш, шулуңайнып-ла чыткан (АT/152)

Baarında hem şaagaynıp, bir-le çüveniñ dugayın tödü çugaalap çadaan ışkaş, şuluñaynıp-la çıtkan.

"Önünde nehir çağlayarak bir şeyle ilgili bütün bilgiler elde edilmemiş nehir gibi şırlldıyormuş (akpp gidiyormuş)."
\end{abstract}

\section{Sonuc}

Çokluk kategorisi kimi zaman net belirli çokluğu işaretlerken kimi zaman belirsiz çokluğu işaretlemektedir. Çalışmamız kapsamında da geniş bir kategori olan çokluk yapısının Tuvacada "çok"

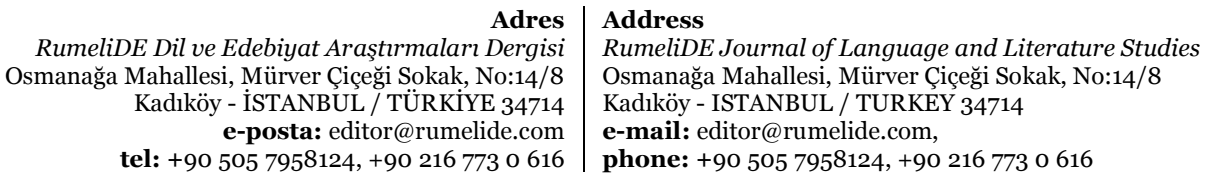


ve "bütün” anlamlarını veren belirsiz çoklukları taranmıştır. Bütünlük anlamında kullanılan sözlerin nesnenin bütünlüğüne değil çokluğuna vurgu yaptığı görülmektedir. Bu kapsamda tespit edilen sözcükler; arbın, dıka, höy, konçug, köp, bügü, bürün, çerle, dögere, hamık, kövey, köñ̃üs, mırinay, şuptu ve tödü sözcükleridir. Bunlardan Tuva gramerlerinde zamir olarak kaydedilen bügü, tödü, hamık gibi sözlerin sentaktik olarak sıfat işlevinde kullanıldığı tespit edilmiştir. Bügü, bürün, şuptu sözcüklerinin yine Tuva gramerlerinde zamir olarak kaydedilirken bizim gramercilik anlayışımıza göre zarf olarak kullanımına dair örnekler tespit edilmiştir. Tuvacada belirsiz çokluk bildiren bu sözlerin çokluğu göstermek olarak cümle içerisinde sentaktik olarak çeşitli işlevlerde kullanıldığı belirlenmiştir. Ayrıca tespit edilen sözlerden arbın, bügü, bürün, şuptu sözlerinin doğrudan Moğolcadan ödünçlendiği görülmektedir.

\section{Taranan eserler:}

AST: Çadraavalın Lodoydamba (2005). Arıg Suglug Tamir. Kızıl: Tıvanıñ Nom Ündürer Çeri.

AT: Salım Sürüñ Ool (1984) Ak Töş. Kızıl: Tuvinskoe Knijno İzdatelstvo.

AY: Ç. Aytmatov (1962). Ayalga. Kızıl: Tivanıñ Nom Ündürer Çeri.

ÇHDB II: Nikolay Luginov (2011). Çiñgis Haannıñ Dujaalı- Bile II. Kızıl: Tıvanıñ Nom Ündürer Çeri.

ÇU: Monguş Kenin Lopsan (2000). Çitken Urug. Kızıl: Tıvanıñ Nom Ündürer Çeri.

DÇÇ: Ekaterina Tanova (2010). Doşkun Çıldarnıñ Çazı. Kızıl: Tivanıñ Nom Ündürer Çeri.

IB: Kızıl Enik Kudajı (1965). Irjim Buluñ. Kızıl: Tıvanıñ Nom Ündürer Çeri.

K: $\quad$ Badı-Bayır Taraaçı (1994). Kaygal. Kızıl: Tıvanı̃ Nom Ündürer Çeri.

\section{Kaynakça}

Clauson, Sir G. (1972), An Etymological dictionary of pre-thirteenth century Turkish, Oxford: Oxford Universty Press. [ED]

Çetin, E. (2017). Altun Yaruk Sekizinci Kitap. Adana: Karahan. [AY VIII]

Çetin, E. (2018). "Eski Uygurcada anlamca çokluk ve topluluk bildiren sözcüklerin kullanım özellikleri - Altun Yaruk örnekleminde-" Yeni Türkiye Türk Dili Özel Sayısl, 66-71.

İlhan, N. (2009). Türk dilinde çokluk. Elazığ: Manas.

İshakov, F. G.\& Palmbah, A. A. (2019), Tuva Dili grameri, ses ve şekil bilgisi, (Ekrem Arıkoğlu, C. M. Bapayeva, B. Borbaanay, Çev.), Ankara: Bengü.

İsina, A. (1997). "Sibirya lehçelerinde çokluk" Sibirya araştırmaları içinde. ( s.113-118). İstanbul: Simurg.

Johanson, L. (2014). Türk dil ilişkilerinde yapısal etkenler. (N. Demir, Çev.). Ankara: TDK.

Kaçalin M. S.\& Ölmez M. (2019). Dîvânu Lugâti't-Turk Mahmûd el- Kâşgarî. İstanbul: Kabalcı.

Koçoğlu Gündoğdu, V. (2018). Tuva Türkçesi grameri metin- söz dizini. Ankara: TDK.

Monguş, D. A. (red.), (2003), Tiva dıldıy tayılbırlıg slovarı, C.I, Novosibirsk: Nauka. [TSTY I]

Monguş, D. A. (red.), (2011), Tiva dıldı刀 tayllbırlıg slovarl, C.II, Novosibirsk: Nauka. [TSTY II]

Ödemiş, Z. (2017). "Tuva Türkçesi ve Türkiye Türkçesinde isimlerde sayı ( teklik -çokluk) kategorisine bir bakış" Uluslararası Türkçe Edebiyat Kültür Eğitim Dergisi, 6(3), 1443-1457.

Ölmez, M. (2007). Tuwinischer wortschatz, Tuvacanın söz varhğı, eski Türkçe ve Moğolca denkleriyle, Wiesbaden: Harrassowitz Verlag [TW]

Tatarintsev, B. İ. (2000). Etimologiçeskiy slovar tuvinskogo yazıka. T.II: D, Yo, A-C / Pod. red. D.A.Monguşa, Novosibirsk: Nauka. [ESTY I]

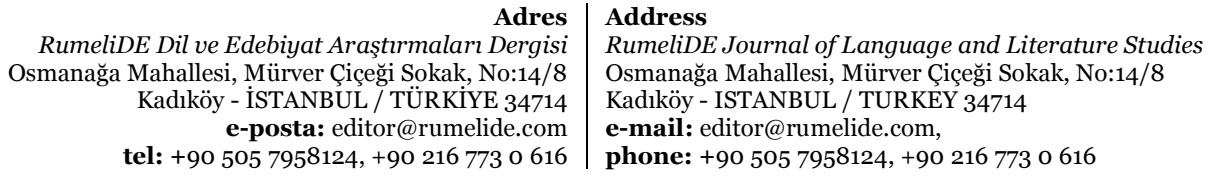

tel: +90 $5057958124,+902167730616$ 
Tatarintsev, B. İ. (2002). Etimologiçeskiy slovar tuvinskogo yazıka. T.II: D, Yo, D, Y / Pod. red. D. A.Monguşa - Novosibirsk: Nauka. [ESTY II]

Tatarintsev, B. İ. (2004). Etimologiçeskiy slovar tuvinskogo yazıka. T.III: K, L - Novosibirsk: Nauka. [ESTY III]

Tatarintsev, B. İ. (2008)Etimologiçeskiy slovar tuvinskogo yazıka. T.IV- M- P Novosibirsk: Nauka. [ESTY IV]

Tenişeva, E. R. ed.(1968). Tuvisko-russkiy slovar'. Moskova: Soveskaya Entsiklopediya. [TuvRus].

Topaloğlu, A. (2019). Karşılaştırmalı dil bilgisi terimleri sözlüğü. İstanbul: Dergâh.

Torun,Y. (2014). "Tarama sözlüğü verilerine göre Türkçede çokluk bildiren fiiller ve birlikte kullanıldı̆̆ı isimlerde sayılabilirlik bağlamında görünümleri” Prof. Dr. Mehmet Özmen Armağanı içinde (s. 295-308). Adana: Çukurova Üniversitesi.

Tosun, İ. (2011). Tuva Türkçesinin şekil bilgisi. Trakya Üniversitesi Sosyal Bilimler Enstitüsü, Yayımlanmamış Doktora Tezi, Edirne

Vardar B. (2002). Açılamalı dilbilim terimleri sözlüğü, İstanbul: Multilingual. 